\title{
SOCIAL CAPITAL, WELL-BEING AND MUNICIPALITY: SALASPILS MUNICIPALITY (LATVIA) CASE
}

\author{
Inga Jēkabsone ${ }^{1}$ and Biruta Sloka ${ }^{2}$ \\ ${ }^{1}$ University of Latvia, Latvia, inga.jekabsone@lu.lv \\ ${ }^{2}$ University of Latvia, Latvia, biruta.sloka@lu.lv
}

\begin{abstract}
During the last three decades, social capital has gained prominence throughout the social sciences. The concepts has been analysed in various manners (from perspectives of economics, political sciences, sociology, anthropology etc.) providing wide range of theoretical conceptualizations. The aim of paper is to analyse the relation of social capital and possibility to improve the well-being of the municipality's citizens using co-responsibility approach. In order to achieve the aim, the tasks are formulated as follows: 1) to review theoretical background for concept of social capital and subjective well-being, 2) to analyse the factors of social capital at local level, and 3) to use the results of conducted empirical research at Salaspils municipality in analysing the correlation of level of social capital and possibility to improve well-being implementing inclusive local management. Research methods used: Scientific literature studies, several stages of focus group discussions, statistical data analysis, SPIRAL methodology, scenario method. The main findings of the paper - there are evidences on relation of social capital and possibility to improve the well-being of the municipality's citizens. In municipalities with sufficient level of social capital are good opportunities to use participatory techniques for achieving higher level of overall well-being. The paper consists of practical value how to mobilise the social capital of the municipality in order to ensure the inclusive management of the territory.
\end{abstract}

Keywords: social capital; social inclusion; municipality; innovative management; subjective well-being.

Type of the paper: Empirical study

JEL Classification: I31, I38, O21, R58.

\section{Introduction}

The concept of social capital became the topic of discussion only relatively recently, but the term has been in use for almost a century while the ideas behind it go back further still. Summarising different definitions (Nenadovic 2015; Lin 2001; Putnam 2000; Burt 2000), it could be concluded that social capital includes the links, shared values and understandings in society that enable individuals and groups to trust each other and so work together. Taking into account recent movements towards implementation of more inclusive government form including society in decision-making processes, the relation between social capital of certain territory and the possibility to involve citizens in improvement of the well-being of that territory contributing with their own resources using so-called co-responsibility approach should be analysed.

Nowadays, taking into account different financial and administrative instruments, the local governments have wide opportunities to affect well-being of society. Indeed, involvement of society in decision-making processes and provision of effective dialogue with society could positively influence the subjective wellbeing, especially if citizens have opportunity to participate with own resources in resolving of topical local issues. These topical issues are described in many researches (see Keating, 2005; Cegarra-Navarro et al., 2012; Almazan \& Garcia, 2008;). 
Within URBACT programme project "Together for territories of co-responsibilities" Salaspils municipality (Latvia) had an opportunity to test the SPIRAL methodology for determination of subjective well-being indicators (see more Jēkabsone et al., 2013). The research methodology was developed by the Council of Europe, providing opportunity to evaluate the personal well-being form the point of view of persons themselves (Council of Europe, 2008). Based on the results of research, the Local Action plan was developed in order to promote the well-being of citizens activating the social capital.

Taking into account all mentioned above, the aim of paper is to analyse the relation of social capital and possibility to improve the well-being of the municipality's citizens using co-responsibility approach.

In order to achieve the aim the tasks are formulated as follows:

1. To review theoretical background for concept of social capital and subjective well-being

2. To analyse the factors of social capital at local level

3. To use the results of conducted empirical research at Salaspils municipality in analysing the correlation of the level of social capital and possibility to improve well-being by implementing inclusive local management.

The following research methods were used: scientific literature studies, several stages of focus group discussions, statistical data analysis, SPIRAL methodology and scenario method.

\section{Social Capital}

The OECD (2001) gives a definition of social capital, consistent with that of Putnam (2000), as "networks together with shared norms, values and understandings that facilitate co-operation within or among groups".

The concept of social capital began to be used in the 1970s as a rehash of ideas not new to sociologists (Portes, 1998). Loury (1977) explains the different degree of success of young people in increasing their human capital using this concept.

According to Putnam: "social capital is a set of features of social organization such as trust, norms and social networks" (Putnam et al., 1993). In subsequent work he states that "social capital refers to interpersonal ties, social networks, reciprocity and trust arising from the ties" (Putnam, 2000). In addition, Putnam stated that "social capital reflects essentially the involvement of individuals in social networks, the creation of reciprocity relations and interpersonal or generalized trust. Trust is considered a prerequisite for involvement in networks of civic engagement and for long-term preservation of social relations" (Putnam, 2000).

Putnam (2000) understands that "what is productive for a social group may be unproductive for another group and he identifies the different consequences of dealing with a bridging social capital (aimed at creating links between groups) or a bonding social capital (aimed at re-establishment of ties of a specific group)". Lin emphasizes the importance of the proactive investment in profitable relationships for the achievement of its own purposes (Lin, 2001). Moreover, Lin (2001) stated that "having access to social capital depends on the individual's position in the social structure, on its role within the network, on the strength of its strong ties (family relationships and friendship) and weak ties (other social relations)".

\section{Social Capital and Well-being}

The concept of well-being refers to the quality of people's lives which is regarded as "a dynamic process, emerging from the way in which people interact with the world around them" (Rees, Bradshaw, Haridhan, \& Keung, 2010). Ben-Arieh et al. argued that "individual well-being is influenced not only by personal attributes, but also by the characteristics of the contextual factors emphasizing the significance of interactions among individuals, family, peers, schools, neighbourhood, the broader community, and 
society at large, the structure and processes of these contexts can facilitate or hinder access to social and material resources which is vital for a human's survival, development, protection and participation" (BenArieh et al., 2001).

Subjective well-being, the self-evaluation that people carry out of their lives, has been proposed (Diener, 1984, 2000; Cummins et al., 2003) as an alternative measure to track the development of societies instead of economic growth and other related objective indicators such as population health, crime and objective security. Past research has demonstrated that social capital produces subjective well-being, and that people with high degree of subjective well-being tend to partake in online community activities through reciprocal adaptation (Helliwell \& Putnam, 2004; Ellison et al., 2007). Putnam (2000) proved that "social capital is a principal driver that promotes healthy and effective democracy". The past literature on social capital reveals that researchers have approached it as a multi-faceted concept composed of social network, trust, civic participation, life satisfaction, and others (Newton, 2006; Putnam, 2000).

Several papers have documented that social capital is strongly correlated with subjective well-being in cross-sections (see the pioneering studies by Helliwell $(2011,2006)$ and Helliwell and Putnam (2004); see also Bruni and Stanca (2008), Becchetti et al. (2008) and Bartolini et al. (2014)).

\section{Social Capital and Municipality}

Sacco and Vanin (2000) declared that "the local dimension is very important in the study of social capital since contains both predominantly, locally occurring shared norms and values of a community and the highest number of interactions between economic actors; a good network of relationships between interest groups and local public institutions can facilitate the improvement of infrastructures and services, and investments". Saxenian (1994) also pointed that "social capital can play an important role in regional development in a globalized world where it can help reduce the costs required for coordination of more and more specialised businesses".

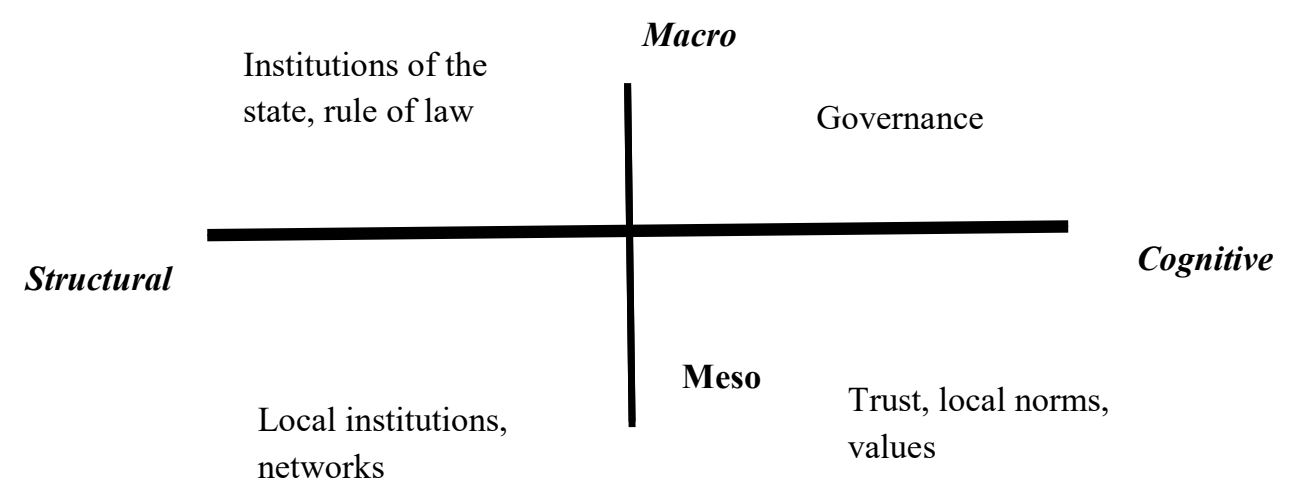

Micro

Fig. 1. The Forms and Scope od Social Capital (Source: Grootaert, Van Bastelaer, 2002)

Municipality's social capital, or more generally, macro-level social capital, is a resource one can access via membership in a group or community. Social capital on the macro-level as opposed to micro-level social capital, which operates exclusively on the individual level consists of norms of reciprocity, civic participation, trust in others, and the benefits of membership. Work by Kawachi, et al. (2008), Putnam (2000), Subramanian et al. (2003), and, in particular, work on the neighbourhood level (Stafford et al., 2008; Van Hooijdonk et al., 2008) provides examples of this macro-level approach to social capital. 
The discussion of social capital according to it forms and scope is illustrated in Fig.2, where specific concepts of structural and cognitive social capita are presented along the continuum from the micro to the macro dimensions.

The breadth of the concept of social capital has been a sign of both strength and weakness of conceptual debate so far. However, at municipal level where citizens have possibility to spend the most part of their leisure time the social capital could be understood better. At local level citizens have an opportunity to build a network and use it for realization of different initiatives and attitudes.

\section{Methodology}

During the research in Salaspils Municipality so-called SPIRAL (Societal Progress Indicators for the Responsibility of All) methodology was used, which provides the way to define and measure well-being from the subjective point of view of the persons themselves. This methodology was approbated in different European cities - more than 100 municipalities tested it according to local circumstances.

During the data collecting citizens of municipality are gathered in homogeneous groups (focus groups) representing all society. Moderator of the groups ask to provide answers to open-ended questions like "What is well-being for you?", "What is not well-being for you?", "What do you do or could do for your well-being?", "What municipality could do for your well-being?". The collected answers are divided in 8 main blocks: 1) access to means of living; 2) living environment; 3) relations with institutions; 4) personal relations; 5) social balance; 6) personal balance; 7) feelings of well-being/ill-being; 8) attitudes and initiatives. Avery block has wide range of possible well-being indicators (URBACT, 2009).

The input data were gathered from different homogeneous groups (focus groups), which in general represent the society of municipality. After conducting research on structure of the society, 25 homogenous groups were gathered for further research. Table 1 shows the analysis of homogeneous groups in Salaspils municipality.

Table 1. The Analysis of Homogeneous Groups in Salaspils Municipality (Source: Author's construction based on observations during the meetings with focus groups)

\begin{tabular}{|l|l|c|c|c|c|}
\hline Society group & Homogeneous groups & $\begin{array}{l}\text { Number of } \\
\text { groups }\end{array}$ & $\begin{array}{l}\text { Level of } \\
\text { participation }\end{array}$ & $\begin{array}{l}\text { Level of } \\
\text { importance }\end{array}$ & $\begin{array}{l}\text { Level of } \\
\text { influence }\end{array}$ \\
\hline Youth & $\begin{array}{l}\text { The Student Councils of Salaspils } \\
\text { First and Second High Schools }\end{array}$ & 5 & Medium & Medium & Low \\
\hline Parents & $\begin{array}{l}\text { School for mothers and babies; } \\
\text { The board of parents of preschools; } \\
\text { society of large families; Salaspils } \\
\text { Women's Club }\end{array}$ & 8 & High & High & Medium \\
\hline $\begin{array}{l}\text { Cultural/ sport/ } \\
\text { religion workers }\end{array}$ & $\begin{array}{l}\text { Russian song ensemble; middle } \\
\text { age dance group; education, culture } \\
\text { and sport department; sport club; } \\
\text { Lutheran church; Roman Catholic } \\
\text { Church }\end{array}$ & 8 & High & High & High \\
\hline Science workers & $\begin{array}{l}\text { Institute of Inorganic Chemistry, } \\
\text { Institute of Physics and Institute of } \\
\text { Biology }\end{array}$ & 3 & Low & Medium & Low \\
\hline $\begin{array}{l}\text { Municipality } \\
\text { workers }\end{array}$ & $\begin{array}{l}\text { Social service; the Union of } \\
\text { municipality workers; council }\end{array}$ & 3 & High & High & High \\
\hline Disabled people & $\begin{array}{l}\text { The association of children and } \\
\text { young people with disabilities; } \\
\text { NGO of disabled persons }\end{array}$ & 3 & High & Medium & High \\
\hline Seniors & Society of Russians; the Board of & 3 & High & Medium & Medium \\
\hline
\end{tabular}




\begin{tabular}{|l|l|c|c|c|c|}
\hline & Salaspils retired people; club & & & & High \\
\hline $\begin{array}{l}\text { Representatives } \\
\text { from rural } \\
\text { territories }\end{array}$ & $\begin{array}{l}\text { Society 'Partnership of Stopini and } \\
\text { Salaspils'; Initiavive group of } \\
\text { citizens of Dole island }\end{array}$ & 2 & High & & \\
\hline TOTAL & 25 & 35 & & & \\
\hline
\end{tabular}

Data gained at the focus group discussions were analysed using the software designed by the Council of Europe. The software program on SPIRAL methodology updates the results of homogeneous group findings, the experts entered the focus group participants' written criteria data, allocating them to the right indicator group and giving estimates.

The overall sequence of researching and promoting well-being methodology approbated in Salaspils Municipality is provided in Fig. 2.

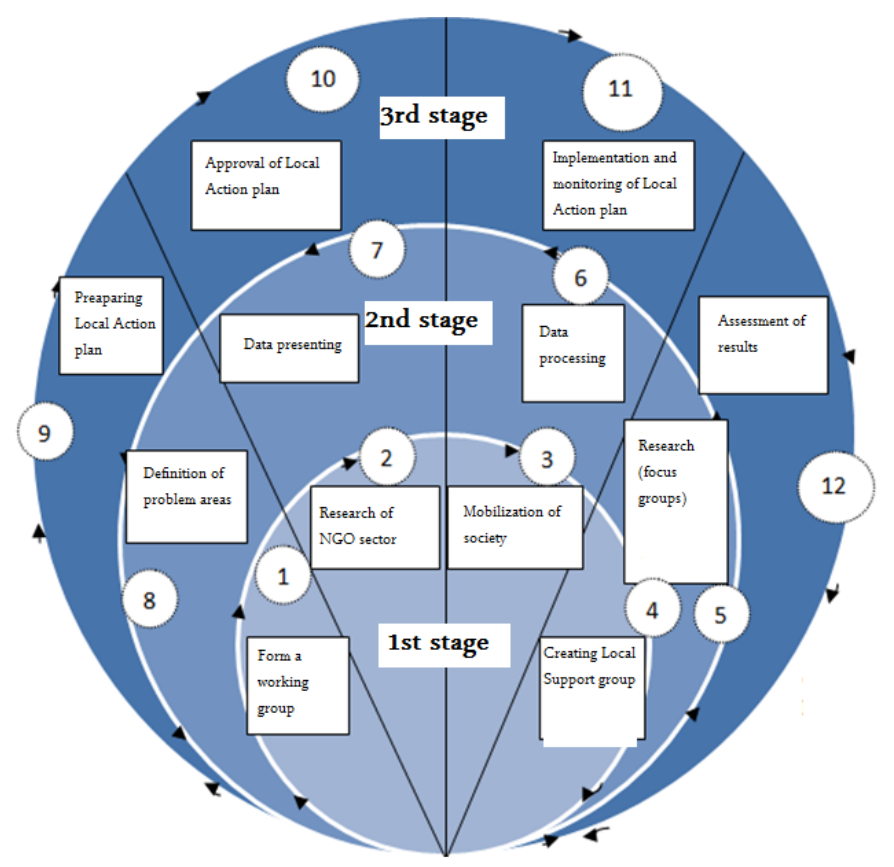

Fig. 2. The sequence of researching and promoting well-being methodology in municipalities (Source: elaborated by the authors)

The first stage is preparation, which includes formation of working group that would provide the research inputs, research of NGO sector at municipality, mobilisation of society to ensure the participation of the to the survey, and creation of local support group from the leaders of NGOs. The second stage is the conduction of research, which includes data collection from focus groups, data processing and presenting to respondents, as well as definition of problem areas according to research data. The last stage is achievement and maintenance of results. This stage includes preparation, corroboration and implementation of local action plan, which includes activities aimed to improve the well-being of municipality, as well as monitoring of results. 


\section{Research Results and Discussion}

According to methodology description mentioned before, research was conducted on 25 focus (homogeneous) groups about well-being dimensions and indicators. The Overall results show (see Fig. 3) that $44 \%$ of the respondents related to well-being dimension 'Access to means of living'. The most popular indicators were: 'Education/training' (249 responds), 'Health' (234 responds), 'Employment/economic activities' (216 responds) and 'Leisure/culture/sports' (177 responds). This subjective well-being dimension concerns rather material circumstances. It relates to the basics of daily life ranging from food and shelter, clothes, education and work to money and information, and contains 11 different categories. Examples of the types of responses to the questions that fall into this category include: "to have a home"; "proper education"; "good salary"; "wide range of social services"; and in response to the ill-being question "no job"; "ill-ness"; "no money"; "bad environment". The second most popular well-being dimension is 'living environment' $-16 \%$ of the responses were related to this dimension. The most popular indicators were: 'Basic infrastructure and amenities' (178 responses), 'Meeting and leisure places' (76 responses), 'Service structure and facilities' (64 responses) and 'Living environment in general' (34 responses). Examples of replies in this category include, "green area", "bicycle paths", "parks with benches" and on the ill-being question examples of replies included "expensive heating", "bad roads" and "no place for NGO". The third most popular well-being dimension is 'attitude and initiatives' (11\% of the responses). Indicators mentioned the most include 'Private activities and initiatives' (122 responses), 'Engagement in civic life' (62 responses) and 'Responsibility' (46 responses). This particular subjective well-being dimension relates to citizen participation. Its seven elements include self-improvement, personal/entrepreneurial initiatives, behaviour and commitment within civic life. Examples of observations are "to be in NGO"; "to realise projects"; "to be social active"; "do some work for community" and on the ill-being side such as "no possibility to realise ideas"; "no new initiatives".

Taking into account that social capital includes different factors related to personal relations, this wellbeing dimension would be further analysed. Overall, $6 \%$ of all responses relate to well-being dimension 'Personal relations'. It has six sub-elements covering personal and sexual relations, family life, friend, relations within the neighbourhood and relations at work. Here examples of observations include "having parents", "good relationship with colleagues", "to have nice neighbours", "to have good friends", "to worry about my daughter", "mobbing at work", "no love in life", "abuse in the family".

As it is illustrated in Fig. 3, the most popular indicators of personal relation dimension of well-being were 'Family life and family relationships', 'Personal relations in general' and 'Relations with friends'. Many respondents admitted that the well-being for them is to have good relationship in family and with surrounding persons.

In order to see what the situation is at each indicators of subjective well-being dimension 'Personal relations', all results of the research were presented to the representatives (mostly leaders) of the homogeneous groups, which participated in the research of data gathering. Afterwards they needed to agree in which situation every indicator is (possibilities: 'very bad situation', 'bad situation', 'medium situation', 'good situation' and 'very good situation'). Further, well-being indicators related to social capital and topics of interest for Salaspils inhabitants are presented (see Table 2). 


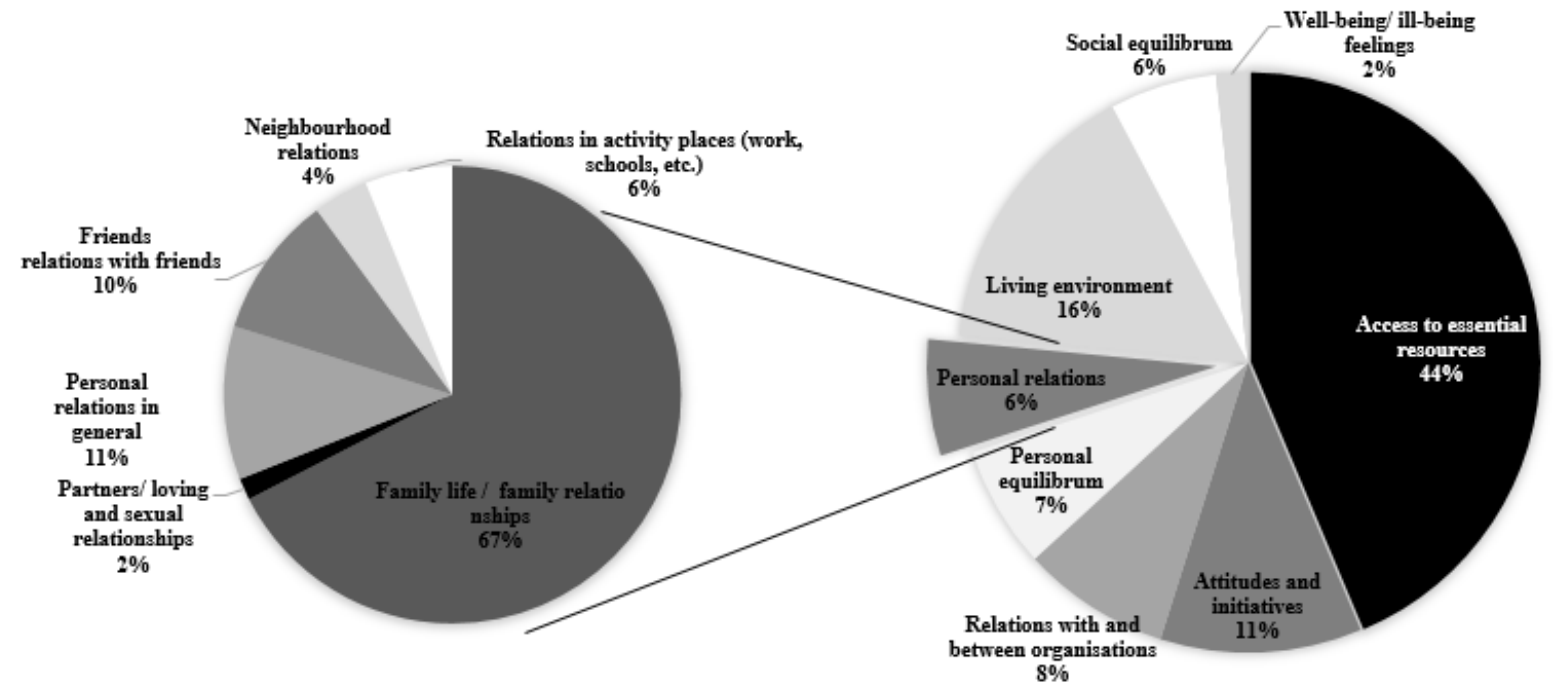

Fig. 3. Indicator Synthesis from Responses in all Homogeneous Groups in Salaspils Municipality in 2011, \% (Source: Results of analysis of 25 homogenous groups in Salaspils - results gained from three meetings from September 2010 until May 2011 (from 2867 responses))

As illustrated in Table 2, the situation of well-being indicators representing social capital is good in Salaspils. That means there are enough pre-conditions for improving overall well-being using coresponsibility approach in decision-making processes as in society with relatively high social capital. Many problems are taken care of by social networking outside of government, and when remaining problems are addressed through governmental intervention, administrators find a rich array of implementation allies.

Table 2. Subjective Well-being Indicators Related to Social Capital in Salaspils Municipality (Source: Results of analysis of 25 homogenous groups in Salaspils - results gained from three meetings. September, 2010 until May 2011(from 2867 responds))

\begin{tabular}{|l|l|l|l|l|l|}
\hline $\begin{array}{l}\text { Well-being } \\
\text { indicator }\end{array}$ & $\begin{array}{l}\text { Family life/ } \\
\text { family } \\
\text { relationships }\end{array}$ & $\begin{array}{l}\text { Personal relations in } \\
\text { general }\end{array}$ & $\begin{array}{l}\text { Relation with } \\
\text { friends }\end{array}$ & $\begin{array}{l}\text { Neighbourhood } \\
\text { relations }\end{array}$ & $\begin{array}{l}\text { Relations in } \\
\text { activity places }\end{array}$ \\
\hline $\begin{array}{l}\text { Very bad } \\
\text { situation }\end{array}$ & $\begin{array}{l}\text { Violence in } \\
\text { families. } \\
\text { Dysfunctional } \\
\text { families. Parents } \\
\text { living abroad. }\end{array}$ & $\begin{array}{l}\text { There is no mutual } \\
\text { respect. There are } \\
\text { intractable conflicts. } \\
\text { People do not listen } \\
\text { to the views of } \\
\text { others. }\end{array}$ & $\begin{array}{l}\text { Loneliness. } \\
\text { No friends. } \\
\text { Friends are not } \\
\text { helping in } \\
\text { need. }\end{array}$ & $\begin{array}{l}\text { Bad relations } \\
\text { with } \\
\text { neighbours. }\end{array}$ & $\begin{array}{l}\text { Bad atmosphere at } \\
\text { work. }\end{array}$ \\
\hline $\begin{array}{l}\text { Bad } \\
\text { situation }\end{array}$ & $\begin{array}{l}\text { No stable } \\
\text { families. Parents } \\
\text { are not taking } \\
\text { care of children. }\end{array}$ & $\begin{array}{l}\text { There is a mutual } \\
\text { aggression, conflict. } \\
\text { There is no love in } \\
\text { society. There is no } \\
\text { harmony. }\end{array}$ & $\begin{array}{l}\text { Virtual } \\
\text { friends. } \\
\text { Inability to get } \\
\text { along with } \\
\text { others. }\end{array}$ & $\begin{array}{l}\text { The neighbours } \\
\text { don't know each } \\
\text { other and don't } \\
\text { help in need. }\end{array}$ & $\begin{array}{l}\text { Bad relationships } \\
\text { with colleagues, } \\
\text { negative emotions } \\
\text { at work. }\end{array}$ \\
\hline $\begin{array}{l}\text { Medium } \\
\text { situation }\end{array}$ & $\begin{array}{l}\text { Stable family, } \\
\text { careful nurturing. } \\
\text { Families spend } \\
\text { their free time } \\
\text { together. }\end{array}$ & $\begin{array}{l}\text { There is mutual } \\
\text { respect, tolerance, } \\
\text { the ability to give } \\
\text { each other } \\
\text { something good. } \\
\text { There are genuine } \\
\text { and honest }\end{array}$ & $\begin{array}{l}\text { Good people } \\
\text { all around, a } \\
\text { lot of friends } \\
\text { who provide } \\
\text { moral support. }\end{array}$ & $\begin{array}{l}\text { Good relations } \\
\text { with } \\
\text { neighbours, } \\
\text { friendly co- } \\
\text { existence. }\end{array}$ & $\begin{array}{l}\text { Employees' needs } \\
\text { are met. Creation } \\
\text { and maintaining of } \\
\text { good relations. }\end{array}$ \\
\hline
\end{tabular}




\begin{tabular}{|c|c|c|c|c|c|}
\hline & & relationships. & & & \\
\hline $\begin{array}{l}\text { Good } \\
\text { situation }\end{array}$ & $\begin{array}{l}\text { Family traditions } \\
\text { and values are } \\
\text { taken care. }\end{array}$ & $\begin{array}{l}\text { There is mutual } \\
\text { understanding. } \\
\text { Tolerant society. }\end{array}$ & $\begin{array}{l}\text { Friends - } \\
\text { representatives } \\
\text { of other } \\
\text { nationalities. }\end{array}$ & $\begin{array}{l}\text { Some traditions } \\
\text { between the } \\
\text { neighbours. } \\
\text { Organisation of } \\
\text { events between } \\
\text { neighbours. }\end{array}$ & $\begin{array}{l}\text { The organisation } \\
\text { meets the needs of } \\
\text { employees. }\end{array}$ \\
\hline $\begin{array}{l}\text { Very good } \\
\text { situation }\end{array}$ & $\begin{array}{l}\text { Every family has } \\
\text { at least two } \\
\text { children. There is } \\
\text { serious attitude } \\
\text { towards the } \\
\text { institution of } \\
\text { marriage. }\end{array}$ & $\begin{array}{l}\text { People respect each } \\
\text { other, help in times } \\
\text { of need. People are } \\
\text { polite. }\end{array}$ & $\begin{array}{l}\text { Good, sincere } \\
\text { relations with } \\
\text { people of } \\
\text { different } \\
\text { groups. }\end{array}$ & $\begin{array}{l}\text { Cross-co- } \\
\text { operative } \\
\text { activities among } \\
\text { neighbours. }\end{array}$ & $\begin{array}{l}\text { No mobbing. } \\
\text { Employees have a } \\
\text { pleasure to go to } \\
\text { work. }\end{array}$ \\
\hline $\begin{array}{l}\text { Situation in } \\
\text { Salaspils } \\
\text { municipality }\end{array}$ & Good situation & Good situation & Good situation & Good situation & Good situation \\
\hline
\end{tabular}

Another result regarding social capital included the level of participation of different NGOs of the municipality. As mentioned before, in the preparation stage of the research, a research about NGO sector in the municipality was undertaken. Overall, 25 NGOs (including non-registered organisations and interest groups) were identified. During the next step, the working group provided an analysis of their participation level in the social life of the municipality (see Table 3). It was concluded that some of the NGOs are insufficiently active (e.g. groups of youth, science workers and disabled persons) and it was decide to pay addition attention to them during the research in order to mobilise their social capital (those groups were selected by the authorities of the municipality as target groups for mobilising social capital).

Table 3. The Analysis of Participation level of NGOs in Salaspils Municipality (Source: Authors' construction based on observations during the meetings with homogeneous groups)

\begin{tabular}{|c|c|c|c|c|}
\hline $\begin{array}{l}\text { Society } \\
\text { group }\end{array}$ & NGOs/ Homogeneous groups & $\begin{array}{l}\text { Number } \\
\text { of groups }\end{array}$ & $\begin{array}{l}\text { Level of } \\
\text { participation before } \\
\text { the research (2010) }\end{array}$ & $\begin{array}{l}\text { Level of } \\
\text { participation after } \\
\text { the research (2013) }\end{array}$ \\
\hline Youth & $\begin{array}{l}\text { The Student Councils of Salaspils First } \\
\text { and Second High Schools }\end{array}$ & 3 & Low & High \\
\hline Parents & $\begin{array}{l}\text { School for mothers and babies; The } \\
\text { board of parents of preschools; society } \\
\text { of large families; Salaspils Women's } \\
\text { Club }\end{array}$ & 4 & Medium & Medium \\
\hline $\begin{array}{l}\text { Cultural/ } \\
\text { sport/ } \\
\text { religion } \\
\text { workers }\end{array}$ & $\begin{array}{l}\text { Russian song ensemble; middle age } \\
\text { dance group; education, culture and } \\
\text { sport department; sport club; Lutheran } \\
\text { church; Roman Catholic Church }\end{array}$ & 4 & High & High \\
\hline $\begin{array}{l}\text { Science } \\
\text { workers }\end{array}$ & $\begin{array}{l}\text { Institute of Inorganic Chemistry, } \\
\text { Institute of Physics and Institute of } \\
\text { Biology }\end{array}$ & 3 & Low & Medium \\
\hline $\begin{array}{l}\text { Municipality } \\
\text { workers }\end{array}$ & $\begin{array}{l}\text { Social service; the Union of } \\
\text { municipality workers; council }\end{array}$ & 3 & High & High \\
\hline $\begin{array}{l}\text { Disabled } \\
\text { people }\end{array}$ & $\begin{array}{l}\text { The association of children and young } \\
\text { people with disabilities; NGO of } \\
\text { disabled persons }\end{array}$ & 3 & Medium & High \\
\hline Seniors & Society of Russians; the Board of & 3 & Medium & Medium \\
\hline
\end{tabular}




\begin{tabular}{|l|l|c|c|c|}
\hline & Salaspils retired people; club & & & Medium \\
\hline $\begin{array}{l}\text { Representati } \\
\text { ves from } \\
\text { rural } \\
\text { territories }\end{array}$ & $\begin{array}{l}\text { Society 'Partnership of Stopini and } \\
\text { Salaspils'; Initiative group of citizens } \\
\text { of Dole island }\end{array}$ & 2 & & \\
\hline TOTAL & 25 & 25 & & \\
\hline
\end{tabular}

During the research, different mobilising techniques were used like helping them to build their administration capacity, improving dialogue with local authorities and administration of municipality, providing premises for the meeting, etc. For example, the municipality announced a project application call for NGOs for organising different events for improvement of overall well-being of society, which encouraged NGOs to work collectively, strengthening social capital. After three years of work, the working group of the research again analysed the participation level of NGOs. It was concluded that the participation level of target groups (youth, science workers and disabled persons) had improved. Those groups were actively participating in social life of the municipality, voluntarily organising different events (like science week, youth award, city festival and many others), participating in regular meetings with administration and political authority of the municipality. Using the co-responsibility approach in identification of well-being indicators and preparation and implementation of local action plan for overall well-being of the municipality, the participation in decision-making processes had increased. Also NGOs were more actively participating in social life of the municipality. Thereby, it also could be concluded that the social capital of the municipality has been mobilised and developed.

\section{Conclusions}

The concept of social capital became topical only relatively recently, but the term has been in use for almost a century while the ideas behind it go back further still. Summarizing different definitions, it could be concluded that social capital includes the links, shared values and understandings in society that enable individuals and groups to trust each other and so work together. There are 2 forms of social capital: a bridging social capital (aimed at creating links between groups) or a bonding social capital (aimed at reestablishment of ties of a specific group).

The concept of well-being could be devided in objective (measured by indicators) and subjective wellbeing (self-assessment of person). During the last decades subjective well-being is on research agenda for many researches as these studies can give significant outputs describing the development of society. In addition, scientific researches documented that social capital is strongly correlated with subjective wellbeing in cross-sections.

It was concluded that studies on social capital with local dimension contains locally occurring shared norms and values of a community and the highest number of interactions between economic actors. A good relationships between society (different NGOs, interest groups) and municipality can facilitate the development of different public services, better governance. Social capital can therefore play an important role in local development reducing resources required for improvement of public services.

Social inclusion and participatory democracy is becoming more and more important across the EU municipalities. Different approaches have been developed to ensure participation of society in the strategic planning processes. These processes are possible due to relatively high social capital and its development. Those approaches are closely related to social inclusion and citizen engagement processes, leading to a society that is more democratic.

Research conducted in Salaspils Municipality shows that mostly society associates personal well-being with access to essential resources (material well-being), good living environment and possibility to realise their attitudes/initiatives. In addition, for citizens personal relations are also important, especially relations with family members, friends, colleagues and neighbours. The indicators analysis showed that in 
Salaspils, the level of those indicators are relatively high, which means that in the municipality there is relatively high social capital. In a society with relatively high social capital, many problems are taken care of by social networking outside of government, and when remaining problems are addressed through governmental intervention, administrators find a rich array of implementation allies.

The research conducted in Salaspils municipality not only shows the clear relation of social capital and well-being but also shows a good practice on how to mobilise the society in municipality with initially low level of participation (forming focus groups for research of well-being, setting up a local support group from leaders of NGOs and interest groups as a public platform, etc.).

\section{Acknowledgements}

The paper was supported by the National Research Program 5.2. 'Economic Transformation, Smart Growth, Governance and Legal Framework for the State and Society for Sustainable Development - a New Approach to the Creation of a Sustainable Learning Community (EKOSOC-LV)'.

\section{References}

Almazan, S., Garcia, G. J.R. (2012). Are government internet portals involving towards more interaction, participation, and collaboration? Revisiting the rhetoric of e - government among municipalities. Government Information Quarterly, 29, 72-88.

Bartolini, S. (2014). Manifesto for Happiness: Shifting Society from Money to Well-being. Pennsylvania University Press.

Becchetti, L., Pelloni, A., Rossetti, F. (2008). Relational goods, sociability and happiness. Kyklos, 61, 343-363.

Ben-Arieh, A., Kaufman, H. N., Andrews, B. A., George, R., Lee, B. J., \& Aber, J. L. (2001). Measuring and monitoring children's well-being. Dordrecht. Netherlands: Kluwer Academic Press.

Bruni, L., Stanca, L. (2008). Watching alone: relational goods, television and happiness. Journal of Economic Behaviour \& Organisation, 65 (3-4), 506-528.

Burt, R.S. (2000).The network structure of social capital. Research in Organizational Behavior, 22, 345-423.

Cegarra-Navarro, J.-G., Pachon, J.R.C., Cegarra, J.L.M. (2012). E-government and citizens engagement with local affairs through e - websites. Journal of Information Management, 32, 469-478.

Council of Europe (2008). Well-being for all. Concepts and tools for social cohesion. Trends in social cohesion $N$ $20,182 \mathrm{p}$.

Cummins, R.A., Eckersley, R., Pallant, J., Van Vugt, J., Misajon, R. (2003). Developing a national index of subjective wellbeing: the Australian unity wellbeing index. Social Indicators Research, 64 (2), 159-172.

Da Cruz, N.F. \& Marques, R.C. (2014). Revisiting the determinants of local government performance, Omega, 4, 91 103.

Diener, E. (1984). Subjective well-being. Psychological Bulletin, 95 (3), 542-575.

Ellison, N. B., Steinfield, C., \& Lampe, C. (2007). The Benefits of Facebook 'Friends' social capital and college students use of online social network sites. Journal of Computer Mediated Communication, 12, 1143-1168.

Evans, P. (1996). Government action, social capital and development: Reviewing the evidence on synergy. World Development, 24(6), 1119-1132.

Folland, S. (2007). Does "community social capital" contribute to population health? Social Indicators Research, 64 (3), 59-75.

Grootaert C., Van Bastelaer, T. (2002). Understanding and Measuring Social Capital: A Multidisciplinary tool for practitioners, The World Bank Publications.

Helliwell, J. (2006). Well-being, social capital and public policy: what is new? The Economic Journal 116, 34-45. 
Helliwell, J. (2011). Institutions as enablers of wellbeing: the Singapore prison case study. International Journal of Well-being, 1, 255-265.

Helliwell, J. F., \& Putnam, R. D. (2004). The social context of well-being. Philosophical Transactions, 359(1449), $1435-1446$.

Jēkabsone, I., Thirion, S., Grantiņ̌s, A., Sloka, B. (2013). Challenges of the SPIRAL Methodology for Well-Being Studies. International conference „NEW CHALLENGES OF ECONOMIC AND BUSINESS DEVELOPMENT 2013” Proceedings, University of Latvia, 339 - 353.

Kawachi, I., Subramanian, S. V., \& Kim, D. (Eds.). (2008). Social capital and health. New York, NY: Springer. Science and Business Media.

Keating, M. (2005). Policy convergence and divergence in Scotland under devolution. Regional Studies, 39, 453 464.

Lin, N. (2001). Social capital: A theory of social structure and action. Cambridge: Cambridge University Press.

Loury, G. (1977). A dynamic theory of racial income differences. In: Wallace, P.A., \& Le Mund, E. (Eds.), Women, minorities and employment discrimination (153-186). Lexington: Lexington Books.

Nenadovic, M. (2015). Participation for Conservation: the Role of Social Capital in Multi-Level Governance of Small-Scale Fisheries. Duke University.

Newton, K. (2006). Political support: Social capital, civil society and political and economic performance. Political Studies, 54, 846-864.

OECD (2001). The evidence on social capital. The Well-being of Nations: The Role of Human and Social Capital. OECD publications, Paris.

Portes, A. (1998). Social Capital: Its Origins and Applications in Modern Sociology. Annual Review of Sociology, $24,1-24$.

Putnam, R. D. (1993). The prosperous community: Social capital and public life. American Prospect, 13, 35-42.

Putnam, R. D. (2000). Bowling alone: The collapse and revival of American community. New York: Simon and Schuster.

Rees, G., Bradshaw, J., Haridhan, G., \& Keung, A. (2010). Understanding children's wellbeing: A national survey of young people's well-being. London: The Children's Society.

Sacco, P.L., \& Vanin, P. (2000). Network interaction with material and relational goods: An exploratory simulation. Annals of Public and Cooperative Economics, 5, 45-63.

Saxenian A. (1994). Regional advantage: Culture and competition in Silicon Valley and route 128. Cambridge: Harvard University Press.

Subramanian, S. V., Lochner, K. A., \& Kawachi, I. (2003). Neighbourhood differences in social capital: a compositional artefact or a contextual construct? Health and Place, 9(1), 33-44.

URBACT (2009). The URBACT Guide to Local Action Plans EAP/MC Retrieved from: http://urbact.eu/fileadmin/general_library/URBACT_LSG_Toolkit_090115.pdf

Van Hooijdonk, C., Droomers, M., Deerenberg, I. M., Mackenbach, J. P., \& Kunst, A. E. (2008). The diversity in associations between community social capital and health per health outcome, population group and location studied. International Journal of Epidemiology, 37(6), 1384-1392.

Woolcock, M. (1998). Social capital and economic development: Forward a theoretical synthesis and policy framework. Theory and Society, 27, 151-208.

Woolcock, M., \& Narayan, D. (2000). Social capital implications for development theory, research, and policy. Social Capital Initiative Working Paper no. 2. Washington D.C.: World Bank. 